\title{
Developmental and moult cycle related biochemical changes in larvae of the spider crab, Maja brachydactyla (Brachyura: Majidae)
}

\author{
GUIOMAR ROTLLANT ${ }^{1}$, GUILLERMO GUERAO ${ }^{1}$, MARTA SASTRE $^{1}$ \\ and KLAUS ANGER ${ }^{2}$ \\ ${ }^{1}$ IRTA, Unitat Operativa de Cultius Experimentals. Ctra. Poble Nou, Km 5.5, 43540 Sant Carles de la Ràpita, Tarragona, \\ Spain. E-mail: guiomar.rotllant@irta.cat \\ ${ }^{2}$ Alfred-Wegener-Institut für Polar- und Meeresforschung; Biologische Anstalt Helgoland, Meeresstation, \\ 27498 Helgoland, Germany.
}

SUMMARY: Ontogenetic changes in dry weight, elemental composition (CHN), and digestive enzyme activities (total protease, amylase) were studied during the moulting cycle of all larval instars (zoea I-II, megalopa; ZI, ZII, M) of the spider crab Maja brachydactyla Balss, 1922 reared in the laboratory. A gradual but significant increase in biomass was observed throughout the zoeal instars, followed by steeper growth in the megalopa. Maximum values were reached in moult stage $\mathrm{D}_{2}$. Digestive enzyme activities also increased significantly throughout larval development. The ZI showed a continuous increase in total protease activity during its moult cycle, suggesting that newly hatched larvae have a gradually increasing need to take up proteins to provide amino acids, which are prime materials for growth and development, and possibly to use them as a metabolic energy source. The largest variations in digestive enzyme activites in relation to the moult cycle were observed in the megalopa instar. After an initial increase in postmoult, enzyme activities decreased to low levels similar to those measured in the zoeal instars at intermoult, followed by another increase to a maximum level in premoult. Metamorphosis involves great physiological and behavioural changes, which could explain the large variations in the megalopa moult cycle. We therefore suggest that the moult cycle stages should be taken into account when nutritional condition indices are used to estimate the physiological performance of decapod crustacean larvae.

Keywords: larvae, dry weight, elemental composition, digestive enzyme, nutritional condition indices.

RESUMEN: CAmbios bioquímicos relacionados con el Ciclo de muda y Desarrollo en las larvas del Cangrejo, MAJA BRACHYDACTYLA (BRAChYURA: MAJIDAE). - Se han estudiado los cambios ontogénicos en peso seco, composición elemental (CHN), y actividad enzimática (proteasas totales, amilasas) durante el ciclo de muda en todos los estadios larvarios (zoea I-II, megalopa; ZI, ZII, M) del centollo Maja brachydactyla Balss, 1922 cultivados en el laboratorio. Se ha observado un incremento gradual y significativo en la biomasa durante los estadios de zoea, seguido de un crecimiento brusco en la megalopa alcanzando valores máximos en el estado de muda $\mathrm{D}_{2}$. La actividad enzimática también aumentó significativamente durante el desarrollo larvario. Las ZI presentaron un continuo incremento de la actividad de las proteasas totales durante el ciclo de muda, sugiriendo que las larvas recién eclosionadas tienen una necesidad inmediata y creciente de utilizar las proteínas como fuente de aminoácidos para el crecimiento y el desarrollo, y posiblemente, como fuente de energía. Las mayores variaciones durante el ciclo de muda en las actividades enzimáticas digestivas se observaron en el estado de megalopa. Después de un incremento inicial en postmuda, las actividades enzimáticas decrecieron a valores bajos comparados con aquellos medidos en los estados de zoea en intermuda y, a continuación, se alcanzaron los niveles máximos en premuda. La metamorfosis implica cambios fisiológicos, los cuales podrían explicar las fuertes variaciones observadas en el ciclo de muda de la megalopa. De ahí que sugiramos que los estadios del ciclo de muda deberían tenerse en cuenta en determinados estadios larvarios cuando se usen índices de condición nutricional para estimar el estado fisiológico de las larvas de crustáceos decápodos.

Palabras clave: larvas, peso seco, composición elemental, enzimas digestivos, índices de condición nutritional. 


\section{INTRODUCTION}

The commercially fished spider crab Maja brachydactyla is considered to be a potentially important target species for aquaculture diversification programmes in Western Europe, particularly in Spain. This species has some interesting features, such as high growth rates and the ability to adapt and reproduce in captivity, where it shows high fecundity and produces several successive egg clutches during the breeding season (Gonzalez-Gurriarán et al. 1998). Like other species of the superfamily Majoidea, $M$. brachydactyla has short planktotrophic larval development characterized by only two zoeal stages and a megalopa stage (Guerao et al. 2008). At a constant temperature of $18^{\circ} \mathrm{C}$, development from hatching to metamorphosis lasts on average 18 days (Andrés et al. 2007, 2008).

As in other species produced in aquaculture, a high number of viable larvae with a good physiological condition is considered crucial for successful culture, because early larval quality affects the future development of later larval and juvenile phase, both in terms of growth and resistance to nutritional stress (Giménez et al. 2004). The development of sustainable rearing techniques therefore requires an in-depth knowledge of critical aspects of larval nutrition in relation to the development of the digestive and metabolic systems. The effects of early feeding conditions on aquatic organisms are generally assessed with a number of indicators commonly referred to as "physiological condition indices". A variety of morphometrical, histological and biochemical parameters are routinely applied to evaluate condition and feeding history in wild and cultured populations of larval fish (Gisbert et al. 2004, Cara et al. 2007, Shan et al. 2009) and crustaceans (Rotllant et al. 2001, 2010, Johnston et al. 2004, Figueiredo et al. 2008).

Compared to fish, using condition indices for crustaceans is more complicated because crustacean growth is associated with ecdysis, i.e. a periodic replacement of the exoskeleton (Hartnoll 1982). During most of its life history the animal is preparing for or recovering from ecdysis through physiological, metabolic, biochemical and behavioural changes (Chang 1995). These changes have been studied and described extensively for adult crustaceans, but the available data suggest that similar changes also occur in the larval stages (for a review see Anger 2001). For instance, larval moult cycles are associated with significant changes in larval biomass, elemental and proximate biochemical composition, respiration rate and digestive enzyme activities (Hirche and Anger 1987, Anger et al. 1989, Harms et al. 1991).

The present study aimed to determine how moulting and development in successive larval stages of the spider crab, M. brachydactyla, affect its biomass and biochemical composition, and which of these criteria could be used as indicators of larval condition.

\section{MATERIALS AND METHODS}

\section{Larval culture}

Adult M. brachydactyla (3 females, 2 males; 150$170 \mathrm{~mm}$ carapace length) were captured off the Atlantic coast of Galicia, Spain, and transported to IRTA (Sant Carles de la Ràpita, Spain). The broodstock was kept in $2000 \mathrm{~L}$ tanks connected to a recirculation unit (IRTAMar®) that provided constant conditions of salinity (36) and temperature $\left(18^{\circ} \mathrm{C}\right)$. The crabs were fed with mussels and fresh crab (Liocarcinus depurator, Macropipus tuberculatus; for details see Andrés et al. 2007). Larval hatching occurred within 1 to 2 months. Actively swimming larvae were collected from broodstock tanks, transferred to $500 \mathrm{~mL}$ rearing beakers $(60$ larvae $\mathrm{L}^{-1} ; \mathrm{n}=50$ ) and then reared at a constant salinity (36) and temperature $\left(18 \pm 1^{\circ} \mathrm{C}\right)$, with a natural photoperiod of ca. $12 \mathrm{~h}$ light per day (early spring condition), and fed daily after each water change with freshly hatched Artemia franciscana nauplii (Great Salt Lake strain, Utah; INVE, Belgium; ca 60 nauplii larva ${ }^{-1}$ day $^{-1}$ ). Larvae that moulted on the same day to the same instar (zoea II, megalopa) were grouped in new beakers. Maximum culture densities were 60 larvae $\mathrm{L}^{-1}$ for the ZII stage and 40 larvae $\mathrm{L}^{-1}$ in the megalopa stage. Larvae were sampled at $24 \mathrm{~h}$ intervals, and five of these were immediately mounted for microscopical observation of 4-5 moult stages (AB, C or A-C, $\mathrm{D}_{0}, \mathrm{D}_{1}$, and $\mathrm{D}_{2}$; Guerao et al. 2010). Another 5 larvae were rinsed in distilled water, blotted on fluff-free Kleenex paper for optical use, and stored at $-18^{\circ} \mathrm{C}$ for later determinations of dry weight and elemental composition. Finally, 20 larvae were rinsed in $\operatorname{cool}\left(4^{\circ} \mathrm{C}\right)$ distilled water and frozen individually at $-80^{\circ} \mathrm{C}$ for later enzyme analysis.

\section{Dry weight (DW) and elemental analysis (CHN)}

Analyses of carbon $(\mathrm{C})$, hydrogen $(\mathrm{H})$ and nitrogen (N) (collectively CHN) were carried out at the Marine Biological Station Helgoland (Alfred Wegener Institute for Polar and Marine Research, BAH/AWI, Germany) following standard techniques (Anger and Harms 1990). Five replicates with three ZI, two ZII or one M were sampled in each moult stage and subsequently stored at $-18^{\circ} \mathrm{C}$. These samples were later lyophilized and the freeze-dried materials were sent by courier to the BAH/AWI. There they were again vacuum-dried at $<10^{-2}$ mbar, weighed to the nearest $0.1 \mu \mathrm{g}$ on a microbalance, and combusted at $1020^{\circ} \mathrm{C}$. The samples were then analysed with an Elemental Vario Micro CHN Analyser using Sulphanilamide as a standard.

\section{Digestive enzyme activities}

A fluorometric analytical technique was chosen to evaluate individual variability (Rotllant et al. 2010). Single larvae were homogenized in $100 \mu \mathrm{L}$ distilled water and sonicated in an ice bath with three short puls- 
es of $2 \mathrm{sec}$ (Vibracell, Sonics, USA). The homogenate was then centrifuged for $5 \mathrm{~min}$ at $13000 \times \mathrm{g}$ at $4^{\circ} \mathrm{C}$, and the extract was used for the analysis of total protease and amylase. For total protease, the larval homogenates were diluted to $1: 10$. Fluorescent casein $(0.3 \%$, Molecular Probes Invitrogen C-2990) was used as a substrate. Ten $\mu \mathrm{L}$ of the diluted homogenate were incubated for 1 hour at $37^{\circ} \mathrm{C}$ with $10 \mu \mathrm{L}$ substrate in 100

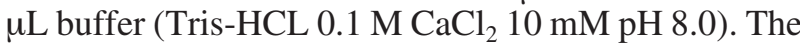
reaction was stopped with $30 \mu \mathrm{L}$ TCA (20\%). After 5 minutes at $4^{\circ} \mathrm{C}$, the mixture was centrifuged for $5 \mathrm{~min}$ at $13000 \times \mathrm{g}$ at $4^{\circ} \mathrm{C}$. Fifty $\mu \mathrm{L}$ of the supernatant were added to a microplate well with $200 \mu \mathrm{L}$ buffer (TrisHCL $0.5 \mathrm{M} \mathrm{pH} \mathrm{8.5).} \mathrm{Fluorescence} \mathrm{was} \mathrm{measured} \mathrm{at}$ $485 \mathrm{~nm}$ (excitation) and $538 \mathrm{~nm}$ (emission) for $2 \mathrm{~min}$ at $30^{\circ} \mathrm{C}$. For amylase, homogenates were diluted to $1: 10$ in Z I, and to 1:50 in ZII and M. The Ultra Amylase Assay Kit (E33651) from Molecular Probes was used for the analysis. Fluorescence was measured at $485 \mathrm{~nm}$ (excitation) and $538 \mathrm{~nm}$ (emission) for $5 \mathrm{~min}$ at $30^{\circ} \mathrm{C}$.

\section{Statistical analysis}

The statistical treatment of the data was performed using a SigmaStat 3 (Systat Software Inc., USA) software package. Ontogenetic changes in DW, elemental biochemical contents and digestive enzymatic activities were tested by one-way ANOVA. After significant differences had been determined, groups were compared using Bonferroni t-tests with an overall significance level of $\mathrm{p}<0.05$.

\section{RESULTS}

The duration of development in successive larval instars reared at $18^{\circ} \mathrm{C}$ increased from 5 days in zoea I to 7 days in the megalopa (Guerao et al. 2010). While larval dry weight (DW) only varied insignificantly within the moult cycles of zoea I and zoea II, intermoult DW increased significantly between the two zoeal instars $(153 \pm 15$ vs $199 \pm 12 \mu \mathrm{g})$. In megalopa, a gradual but significant increase in DW was observed, and the postmoult and intermoult values were similar to those of premoult ZII, followed by a steeper increase to a maximum $(479 \pm 25 \mu \mathrm{g})$ reached in stage $D_{2}$ of the moult cycle (Fig. 1A). Like the DW, the contents of carbon, hydrogen and nitrogen (CHN, in $\mu \mathrm{g}$ DW per individual) increased significantly throughout the larval development period (Fig. 1). The C content, for instance, increased in ZI from an initial value of $36 \pm 2 \mu \mathrm{g}$ at hatching to a maximum value of $57 \pm 3 \mu \mathrm{g}$ in premoult (stage $\mathrm{D}_{1}$ ), in ZII to $70 \pm 9 \mu \mathrm{g}$ in early premoult (stage $\mathrm{D}_{0}$ ), and in megalopa to $151 \pm 9 \mu \mathrm{g}$ prior to metamorphosis (stage $\mathrm{D}_{2}$ ) (Fig. 1B). Similar increasing patterns were also observed in the $\mathrm{N}$ and $\mathrm{H}$ contents (Fig. 1C, D).

The CHN percentages (in \% of DW; not shown) varied little during larval development (C: $28-34 \%, \mathrm{~N}$ : 6.4-7.5\%; H: 5.1-6.2\%), and did not show any clear

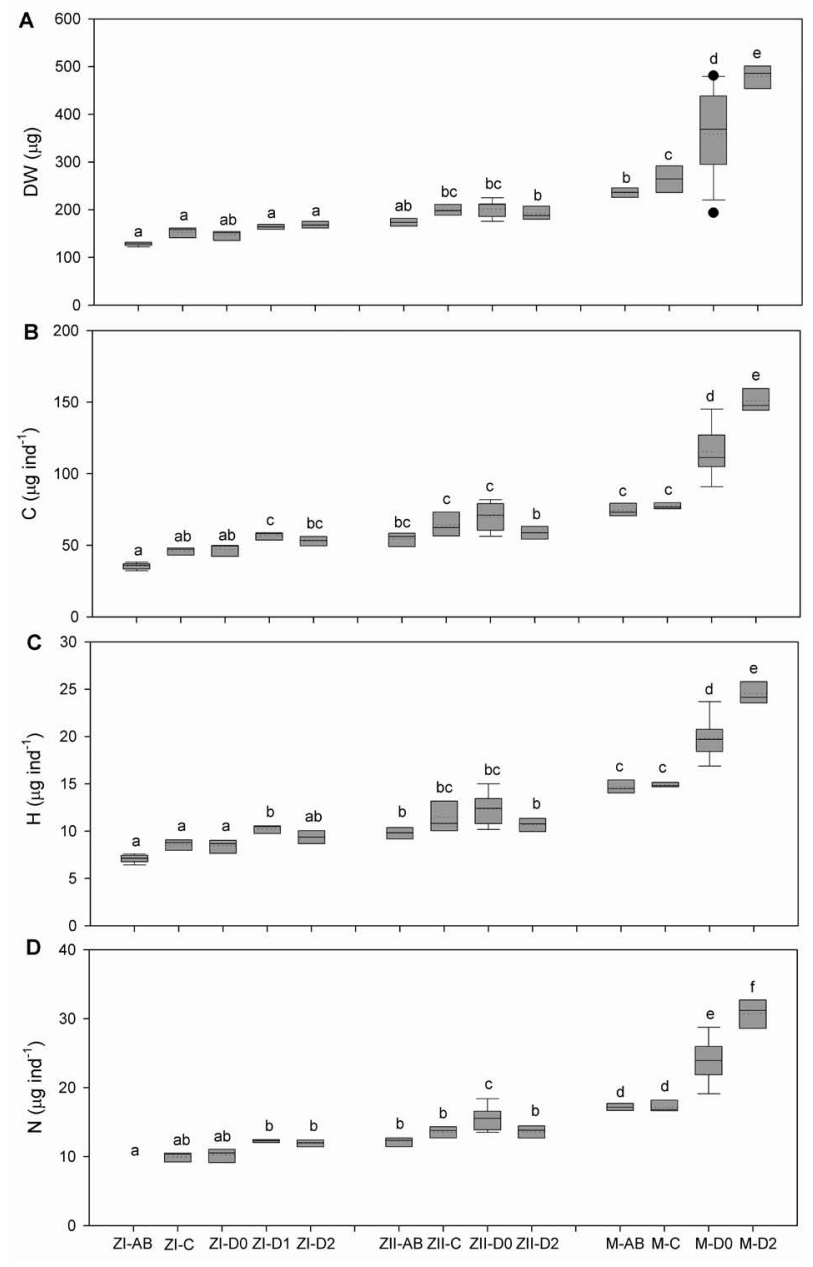

Fig. 1. - Developmental changes in larval biomass and elemental composition of the spider crab, Maja brachydactyla. A, dry weight (DW); B, carbon (C); C, hydrogen $(\mathrm{H})$; D, nitrogen (N) (all in $\mu \mathrm{g}$ per individual); moult stages within successive larval instars (ZI, zoea I; ZII, zoea II; M, megalopa): postmoult (AB), intermoult (C), premoult $\left(\mathrm{D}_{0}, \mathrm{D}_{1}, \mathrm{D}_{2}\right)$. Lower case letters indicate significant differences (Bonferroni t-test, $\mathrm{P}<0.05$ ) between moult stages.

trends in relation to successive larval development or moult cycle stages.

Digestive enzyme activities increased significantly throughout larval development (Fig. 2). Total protease activities were lower in newly hatched ZI $(1624 \pm 689$ $\mathrm{IU}_{\text {ind }}{ }^{-1}$; early postmoult stage $\mathrm{AB}$ ) than in later moulting ZI stages (>3500 IU ind ${ }^{-1}$ in postmoult stages $\mathrm{D}_{1}$ and $\mathrm{D}_{2}$ ). A slight but significant increase in protease activity occurred in ZII, from postmoult (similar values as in late ZI) to a maximum in late premoult $(3756 \pm 904$ IU ind ${ }^{-1}$, stage $\mathrm{D}_{2}$ ). Again, the early postmoult stage of megalopa showed similar protease activity as ZII at intermoult and premoult, but this was followed by a minimum at intermoult $\left(3249 \pm 9789 \mathrm{IU}\right.$ ind $\left.^{-1}\right)$ and significantly increasing values in premoult (Fig. 2A). Amylase activity increased from $4 \pm 2 \mathrm{IU}_{\text {ind }}{ }^{-1}$ at hatching to a value of $81 \pm 42 \mathrm{IU}_{\text {ind }}^{-1}$ in the premoult megalopa instar, in which minimum activity occurred again 

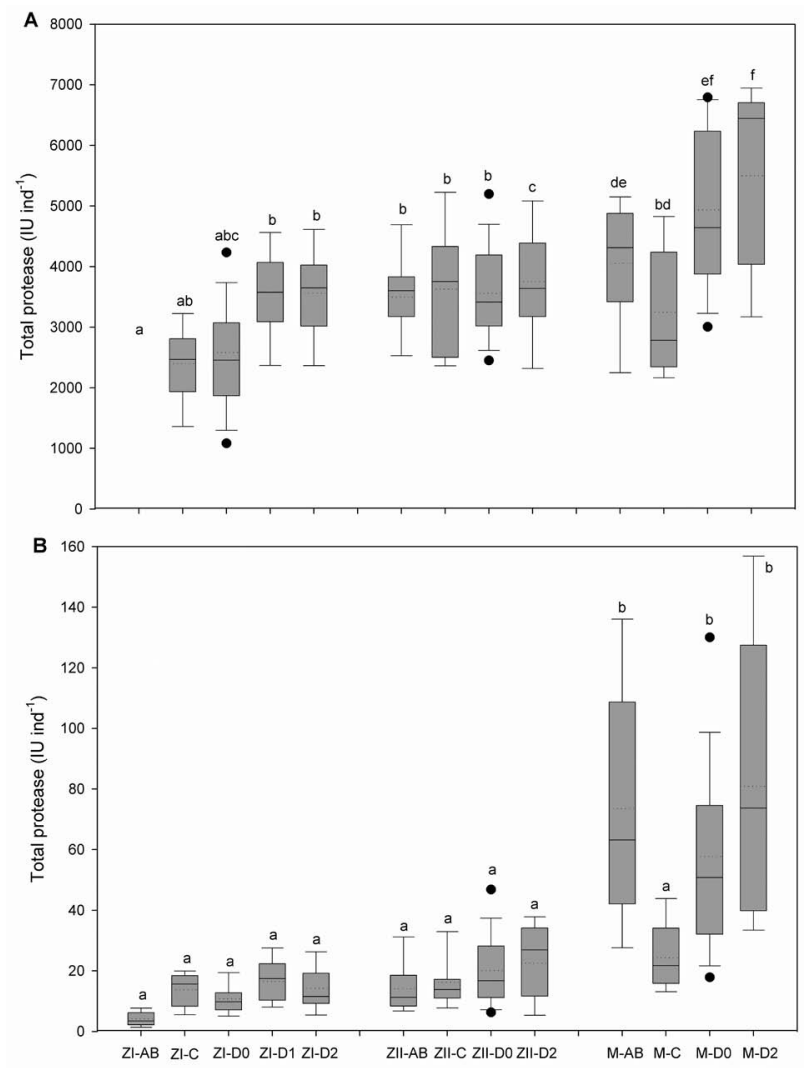

FIG. 2. - Developmental changes in digestive enzyme activities of larvae of the spider crab, Maja brachydactyla. A, total protease; B, amylase (IU ind ${ }^{-1}$ ); moult stages within successive larval instars (ZI, zoea I; ZII, zoea II; M, megalopa): postmoult (AB), intermoult (C), premoult $\left(\mathrm{D}_{0}, \mathrm{D}_{1}, \mathrm{D}_{2}\right)$. Lower case letters indicate significant differences (Bonferroni t-test, $\mathrm{P}<0.05$ ) between moult stages.

at intermoult, while significantly higher values were measured both in the postmoult and premoult stages (Fig. 2B).

\section{DISCUSSION}

The increasing patterns in biomass and digestive enzyme activities during the early ontogeny of Maja brachydactyla fluctuated between successive larval moult stages; however, statistically significant differences were only observed at the megalopa stage, which also had the longest development duration. Previous studies on the same species (Anger and Harms 1990) reported a maximum dry weight of about $160 \mu \mathrm{g}$ for the ZI instar, $224 \mu \mathrm{g}$ for ZII, and $275 \mu \mathrm{g}$ for megalopa, whereas Andrés et al. (2008) found a maximum of $389 \mu \mathrm{g}$ in megalopa. In the present study, newly hatched ZI were heavier than in the two previous studies, and megalopa even reached $479 \mu \mathrm{g}$ in stage $\mathrm{D}_{2}$ (i.e. prior to metamorphosis). Differences were also observed among these studies in maximum CHN data for successive stages, which indicates that there is significant variability among broods produced by different females. Intraspecific variability in larval biomass has also been previ- ously observed in another majoid crab, Hyas araneus (Anger et al. 1989). Moreover, differences observed between studies might also, at least in part, be due to geographic variations among conspecific populations (cf. Andrés et al. 2008, and present study: northwestern Spain; Anger and Harms 1990: French coast of the channel region).

In our study, the carbon, hydrogen and nitrogen ( $\mathrm{CHN}$, in $\mu \mathrm{g}$ per individual) content increased significantly during larval development, as did the total DW. Moreover, we observed moult cycle related changes in the biomass of individual larval instars. For instance, decreasing CHN values occurred in both zoeal instars at moult stage $\mathrm{D}_{2}$, although significant differences were only observed in the $\mathrm{N}$ and $\mathrm{C}$ fractions when moult stages $\mathrm{D}_{0}$ and $\mathrm{D}_{2}$ of the ZII instar were compared (N: $14 \pm 1$ IU $^{-1} d^{-1}$ vs $16 \pm 2$ IU $^{-1}$; C: $59 \pm 5 \mathrm{IU}$ ind $^{-1}$ vs $70 \pm 9 \mathrm{IU}_{\text {ind }^{-1}}$ ). In the majid crab, Hyas araneus, moult cycle related variations were significant in all development instars (Anger et al. 1989). Higher temporal resolution in the sampling of $M$. brachydactyla larvae would probably allow us to differentiate moult cycle related fluctuations better, as observed in the megalopa instar.

Anger et al. (1989) correlated daily food ingestion rates with weight gain rates for $H$. araneus, and found maximum values in postmoult and intermoult, and minimum values in late premoult. Similar changes in feeding activity may also explain the growth patterns observed in the zoeal instars of $M$. brachydactyla, as megalopa showed increasing DW and CHN values throughout premoult. With analyses of individual (using fluorometry, as in the present study) and pooled samples (using spectophotometry), Rotllant et al. (2008) demonstrated that trypsin, amylase and esterase activities in $M$. brachydactyla differ significantly between ZI at hatching and the megalopa instar. Andrés et al. (2010) found a similar ontogenetic increase for total protease in pooled samples. Our present work showed, in addition, significant differences within individual moult cycles. In ZI, for instance, total protease activity increased continuously. This indicates that ZI larvae have a continuously increasing need for protein degradation, which yields amino acids that are used for growth, development and as a metabolic energy source. In contrast, total protease activity in ZII and amylase activity in both zoeal instars remained constant throughout the moult cycle.

The largest moult cycle related variations in digestive enzyme activities were observed in the megalopa instar (Fig. 2). We suggest that the high energetic costs of metamorphosis, in which the animals undergo great morphological and physiological changes, are associated with a change from pelagic to benthic behaviour. This change requires large quantities of proteins and carbohydrates, which may explain the increasing digestive enzyme activity near the end of the megalopa moult cycle. Hirche and Anger (1987) and Harms et al. (1991) showed that trypsin and amylase activities in 
successive larval stages of Hyas araneus also increase during development, like the total protease activity in the present study. In M. brachydactyla, however, there was a different moult cycle related pattern of change in the megalopa instar, with minimum digestive enzyme activity at intermoult. In contrast, high values were observed in $H$. araneus, coinciding with maximum food consumption (Anger et al. 1989). The largest differences between these two majid species were observed in premoult: the megalopa of $H$. araneus showed very low activities prior to metamorphosis, while $M$. brachydactyla showed maximum values for both enzymes. This suggests that late larvae of closely related species have different physiological and behavioural characteristics. Future studies of the nutritional needs and physiological response to food availability of spider crab larvae should therefore enhance the temporal resolution of the analyses of individual moult cycles so that common patterns as well as species-specific differences can be identified and explained.

The present study showed that there are moult cycle related variations in dry weight, elemental composition, and digestive enzyme activities in all larval stages of $M$. brachydactyla, and the largest changes were observed in the megalopa instar. Anger et al. (1985) and Harms et al. (1991), studying the effect of starvation on lobsters (Homarus americanus) and of different diets on spider crabs (Hyas areneus), found significant moult cycle related changes in successive larval instars. Several nutritional studies on the early developmental stages of majoid crabs (Anger et al. 1981, Dawirs 1983, Figuereido et al. 2008, Rotllant et al. 2010) and other decapod crustaceans (Dawirs 1983, Harms et al. 1994, Ritar et al. 2003, Johnston et al. 2004; Figueiredo and Narciso 2006, Sánchez-Paz et al. 2007) have also used various biochemical parameters as nutritional indices, but none of these studies took into account the moult stages within individual larval or postlarval instars. The present study, as well as the studies of Anger et al. (1985) and Harms et al. (1991), demonstrate that there are moult cycle related changes in the biomass and biochemical parameters of larval and postlarval crabs. This shows that it is necessary to determine moult stages when enzymatic activities or other nutritional condition indices are used for assessing rearing conditions for economically important decapod crustacean species.

\section{ACKNOWLEDGEMENTS}

Bench fees were funded by INIA (RTA200800003-00-00 project) to GR. Financial support was provided by the Ministry of Science and Research to GG (post-doctoral fellowship; INIA). The authors would like to thank Glòria Macià and Sandra Molas for their support as hatchery and laboratory technicians at IRTA, Sant Carles de la Ràpita, and Julia Haafke at AWI, Helgoland, for the CHN analyses.

\section{REFERENCES}

Andrés M., Estévez A., Rotllant G. 2007. Growth, survival and biochemical composition of spider crab Maja brachydactyla (Balss, 1922) (Decapoda: Majidae) larvae reared under different stocking densities, prey: larva ratios and diets. Aquaculture 273: 494-502.

Andrés M., Estévez A., Anger K., Rotllant G. 2008. Growth and biochemical composition during larvar and early juvenile development of the spider crab, Maja brachydactyla (Decapoda: Majidae). J. Exp. Mar. Biol. Ecol. 357(1): 35-40.

Anger K., Storch V., Anger V., Capuzzo J.M. 1985. Effects of starvation on molt cycle and hepatopancreas of stage-I lobster (Homarus americanus) larvae. Helgol. Wiss. Meeresunters 39(2): 107-116.

Anger K., Dawirs R.R., Anger V., Costlow J.D. 1981. Effects of early starvation periods on zoeal development of brachyuran crabs. Biol. Bull. 161(2): 199-212.

Anger K., Harms J., Püschel C., Seeger B. 1989. Physiological and biochemical changes during the larval development of a brachyuran crab reared under constant conditions in the laboratory. Helgol. Wiss. Meeresunters 43: 225-244.

Anger K., Harms J. 1990. Elemental (CHN) and proximate biochemical composition of decapod crustacean larvae. Comp. Biochem. Physiol. 97B (1): 69-80.

Chang E.S. 1995. Physiological and biochemical changes during the molt cycle in decapod crustaceans: an overview. J. Exp. Mar. Biol. Ecol. 193: 1-14.

Cara B., Moyano F.J., Zambonino JL, Fauvel C. 2007. Trypsin and chymotrypsin as indicators of nutritional status of post-weaned sea bass larvae. J. Fish Biol. 70(6): 1798-1808.

Dawirs R.R. 1983. Respiration, energy balance and development during growth and stravation of Carcinus maenas L. larvae (Decapoda: Portunidae). J. Exp. Mar. Biol. Ecol. 69: 105-128.

Figueiredo J., Narciso L. 2006. Productivity improvement of Lysmata seticaudata (Risso, 1816) larval rearing protocol through modelling. Aquaculture 261: 1249-1258.

Figueiredo J., Penha-Lopes G., Narciso L., Lin J. 2008. Effect of starvation during late megalopa stage of Mithraculus forceps (Brachyura: Majidae) on larval duration, synchronism of metamorphosis, survival to juvenile, and newly metamorphosed juvenile size. Aquaculture 274: 175-180.

Giménez L., Anger, K. Torres G. 2004. Linking life history traits in succesive phases of a complex life cycle: effects of larval biomass on early juvenile development in an estuarine crab, Chasmagnatus granulata. Oikos 104 (3): 570-580.

Gisbert E., Piedrahita R.H., Conklin D.E. 2004. Effects of delayed first feeding on the nutritional condition and mortality of California halibut larvae. J. Fish Biol. 64: 116-132.

González-Gurriarán E., Fernández, L., Freire J., Muiño R. 1998. Mating and role of seminal receptacles in the reproductive biology of the spider crab Maja squinado (Decapoda, Majidae). $J$. Exp. Mar. Biol. Ecol. 220(2): 269-285.

Guerao G., Pastor E., Martin J., Andrés M., Estévez A., Grau A., Duran J., Rotllant G. 2008. The larval development of Maja squinado and M. brachydactyla (Decapoda, Brachyura, Majidae) described from plankton collected and laboratory-reared material. J. Nat. Hist. 42(33-34): 2257-2276.

Guerao G., Rotllant G., Anger K. 2010. Characterization of larval moulting cycles in Maja brachydactyla (Brachyura, Majidae) reared in the laboratory. Aquaculture 302: 106-111.

Harms J., Anger K., Klaus S., Seeger B. 1991. Nutritional effects on ingestion rate, digestive enzyme-activity, growth, and biochemical-composition of Hyas-araneus L (Decapoda, Majidae) larvae. J. Exp. Mar. Biol. Ecol. 145 (2): 233-265.

Harms J., Meyer-Harms B., Dawirs R.R., Anger K. 1994. Growth and physiology of Carcinus maenas (Decapoda, Portunidae) larvae in the field and in laboratory experiments. Mar. Ecol. Prog. Ser. 108: 107-118.

Hartnoll R.G. 1982. Growth. In: Bliss D.E., Mantel L.H. (eds). Vol. 2. Embryology, Morphology and Genetics. The Biology of Crustacea. Academic Press, New York. pp. 111-196.

Hirche H.J., Anger K. 1987. Digestive enzime activities during larval development of Hyas araneus (Decapoda, Majidae). Comp. Biochem. Physiol. Part B Biochem. Mol. Biol. 87 (2): 297-302.

Johnston D.J., Ritar A.J., Thomas C.W. 2004. Digestive enzyme 
profiles reveal digestive capacity and potential energy sources in fed and starved spiny lobster (Jasus edwardsii) phyllosoma larvae. Comp. Biochem. Physiol. B 138: 137-144.

Ritar A.J., Dunstan G.A., Crear B.J., Brown M.R. 2003. Biochemical composition during growth and starvation of early larval stages of cultured spiny lobster (Jasus edwarsii) phyllosoma Comp. Biochem. Physiol. A 136(2): 353-370.

Rotllant G., Charmantier-Daures M., Charmantier G., Anger K., Sardà F. 2001. Effect of diet on the larval and postlarval development of Nephrops norvegicus. J. Shellfish Res. 20(1): 347-352.

Rotllant G., Moyano F.J., Andrés M., Díaz M., Estévez A., Gisbert E. 2008. Evaluation of fluorogenic substrates in the assessment of digestive enzymes in a decapod crustacean Maja brachydactyla larvae. Aquaculture 282(1-4): 90-96.

Rotllant G., Moyano F.J., Andrés M., Estévez A., Díaz M., Gisbert
E. 2010. Effect of delayed first feeding on the nutritional condition of the spider crab Maja brachydactyla larvae. Mar. Biol. 157: 2215-2227.

Sánchez-Paz A., García-Carreño F., Hernández-López J., MuhliaAlmazán A., Yepiz-Plascencia G. 2007. Effect of short-term starvation on hepatopancreas and plasma energy reserves of the Pacific white shrimp (Litopenaeus vannamei). J. Exp. Mar. Biol. Ecol. 340: 184-193.

Shan X.J., Huang W., Cao L., Xiao Z.Z., Dou S.Z. 2009. Ontogenetic development of digestive enzymes and effect of starvation in miiuy croaker Miichthys miiuy larvae. Fish Physiol. Biochem. 35: 385-398.

Scient. ed.: J.B. Company.

Received October 20, 2010. Accepted November 7, 2011.

Published online March 20, 2012. 